\title{
ResearchOnline@JCU
}

This is the author-created version of the following work:

Williams, Alan N., Ulm, Sean, Goodwin, Ian D., and Smith, Mike (2010) Huntergatherer response to late Holocene climatic variability in northern and central Australia. Journal of Quaternary Science, 25 (6) pp. 831-838.

Access to this file is available from:

https://researchonline.jcu.edu.au/15694/

Published Version: (C) John Wiley. Accepted Version: Open access after a twelve month embargo.

Please refer to the original source for the final version of this work: 


\section{Hunter-Gatherer Response to Late Holocene Climatic Variability in Northern and Central}

Australia

Alan N. Williams ${ }^{\mathrm{a},{ }^{*}}$, Sean Ulm ${ }^{\mathrm{b}}$, Ian D. Goodwin ${ }^{\mathrm{c}}$ and Mike Smith ${ }^{\mathrm{a}, \mathrm{d}}$

${ }^{a}$ Fenner School of Environment and Society, Australian National University, Canberra, Australian Capital Territory, Australia

${ }^{\mathrm{b}}$ Aboriginal and Torres Strait Islander Studies Unit, University of Queensland, Brisbane, Queensland, Australia

${ }^{\mathrm{c}}$ Climate Futures at Macquarie and Environmental Science, Macquarie University, New South Wales, Australia

${ }^{\mathrm{d}}$ Centre for Historical Research, National Museum of Australia, Canberra, Australian Capital Territory, Australia

* Corresponding author: alan.williams@anu.edu.au 


\begin{abstract}
Sum probability analysis of 1275 radiometric ages from 608 archaeological sites across northern and central Australia demonstrates a changing archaeological signature that can be closely correlated with climate variability over the last $2 \mathrm{ka}$. Results reveal a marked increase in archaeological records across northern and central Australia over the last $2 \mathrm{ka}$, with notable declines in western and northern Australia between ca. AD 700 and 1000 and post-AD 1500 - two periods broadly coeval with the Medieval Climatic Anomaly and the Little Ice Age as they have been documented in the Asia-Pacific region. Latitudinal and longitudinal analysis of the dataset suggests the increase in archaeological footprint was continent wide, while the declines were greatest from 9 to $20^{\circ} \mathrm{S}, 110$ to $135 \mathrm{E}$ and 143 to $150^{\circ} \mathrm{E}$. The change in the archaeological data suggests that, combined with an increase in population over the late Holocene, a disruption or reorganisation of pre-European resource systems occurred across Australia between ca. AD 700 and 1000 and post-AD 1500. These archaeological responses can be broadly correlated with transitions of the El Niño-Southern Oscillation (ENSO) mean state on a multi-decadal to centennial timescale. The latter involve a shift towards the La Niñalike mean state with wetter conditions in the Australian region between AD 700 and 1150. A transition period in ENSO mean state occurred across Australia during AD 1150-1300, with persistent El Niño-like and drier conditions to ca. AD 1500, and increasing ENSO variability post-AD 1500 to the present.
\end{abstract}

Keywords: Human-Environment Interaction; El Niño-Southern Oscillation; Medieval Climatic Anomaly; Little Ice Age; Australia. 


\section{Introduction}

Aboriginal hunter-gatherer populations in central and northern Australia were strongly impacted by climatic variability affecting the strength of summer monsoon rainfall. Archaeological and ethnographic data suggest that hunter-gatherers developed systems of mobility (Meggitt, 1962; Gould, 1969; Tonkinson, 1978; Myers, 1991) and technology (Hiscock, 1994; Attenbrow et al., 2009) to stabilise fluctuations in resource availability. Studies of hunter-gatherer demography also indicate that prehistoric hunter-gatherer societies were marked by significant periods of population collapse and recovery during periods of environmental instability (Davidson, 1990; Pennington, 2001; Smith et al., 2008).

Such human responses are evident in the late Holocene - a period of increased El Niño-Southern Oscillation (ENSO) activity (Turney and Hobbs, 2006; Williams et al., 2008a). Following an initial period of wetter conditions, ENSO intensified in strength and frequency, leading to drier and more variable conditions across Australia between 3.7 and 2 ka (Shulmeister, 1999; Gagan et al., 2004; Donders et al., 2007). During this period, the use of hafting technology, the appearance/proliferation of microlithic tools (e.g. tula adzes and backed blades) and the standardisation of stone tools all occur for the first time (Hiscock and Veth, 1991; Hiscock, 1994; Thorley, 1998; Veth, 2005; Attenbrow et al., 2009). Radiocarbon data further suggest that populations in arid Australia may have contracted in response to increased aridity at around $3 \mathrm{ka}$ (Smith et al., 2008; Williams et al., 2008a).

Several studies suggest that hunter-gatherer populations increased significantly after $2 \mathrm{ka}$ (e.g. Williams, 1988; Veth, 1993; Lourandos and Ross, 1994; Lourandos and David, 1998; Cosgrove et al., 2007; Smith and Ross, 2008; Ulm, 2010) - with Smith and Ross (2008) showing that the critical transition in arid central Australia dates around 0.9-1 ka The contrary view is that these changes represent changes in settlement pattern and use of archaeological sites, rather than population, or alternatively the taphonomic loss of older archaeological sites (e.g. Ross, 1986; Rowland, 1989; Attenbrow, 2004; Hiscock, 2008; Holdaway et al., 2008; Surovell and Brantingham, 2007; Surovell et al., 2009). Whatever the case, the last 2 ka encompass a series of adaptive responses to climatic variability, including an increase in use of marginal and outlying sites, the extended use of existing sites, increased territoriality expressed through greater differentiation of rock art, and more intensive use of lower calorific food resources, such as plant food processing (Smith, 1986; Cosgrove et al., 2007; Smith and Ross, 2008; cf. Edwards and O'Connell, 1995; Holdaway et al., 2008).

Here, we explore hunter-gatherer response to climatic variability over the last $2 \mathrm{ka}$, with particular reference to the changing state of ENSO. We use an analysis of sum probability distributions of 1275 radiocarbon ages from 608 archaeological sites (Figure 1) to explore the relationship between archaeological records and palaeoclimatic records across central and northern Australia. Our data show that there was significant variability in patterns of prehistoric occupation within the late Holocene. 


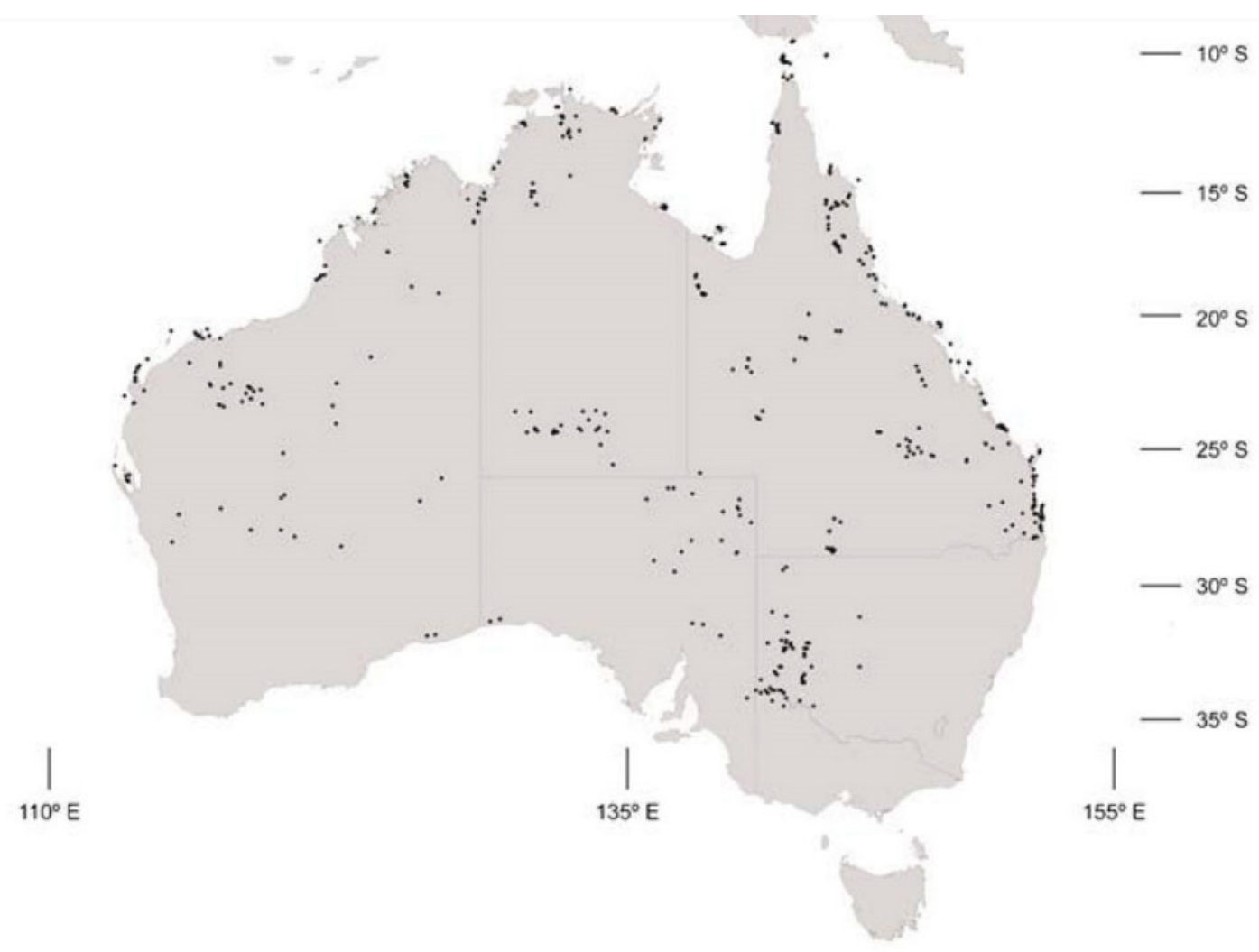

Figure 1. Map of archaeological sites. 


\section{Methods, data and limitations}

Sum probability distributions have been widely adopted in both archaeology and palaeoclimatology to generate continuous time series records (e.g. Rick, 1987; Gamble et al., 2005; Johnstone et al., 2006; Turney and Hobbs, 2006; Turney et al., 2006; Fiedel and Kuzmin, 2007). The approach compiles large datasets of radiometric data into a single time series curve and permits the investigation of largescale temporal and spatial changes within a region. It further allows formal statistical comparisons and correlations with other proxies to be explored (Smith et al., 2008).

The relationships between climatic events and human responses is well documented. Although humans do not mechanistically respond to environmental change, the availability of essential resources (food and water) significantly constrains human choices (e.g. Stine, 1994; Barlow et al., 1997; Nunn, 2003; Diamond, 2005; Tainter and Crumley, 2007).

Radiometric data for the last $2 \mathrm{ka}$ are assembled for the northern two-thirds of Australia $\left(9-35^{\circ} \mathrm{S}\right)$ and analysed by latitude ( $5^{\circ}$ increments) and longitude (divided between $110-135^{\circ} \mathrm{E}$ and $135-155^{\circ} \mathrm{E}$ ) (Ulm and Reid, 2000; Williams et al., 2008b; see supporting information). A total of 1275 radiometric ages, a subset of a larger database of over 2600 dates encompassing all published radiometric ages for central and northern Australia for the last $40 \mathrm{ka}$, were used for this analysis. Following established protocols, several erroneous or anomalous dates were discounted from the analysis (see supporting information).

Radiocarbon data were calibrated with OxCal 4.1 (Bronk Ramsey, 2001). Terrestrial ages were calibrated with SHCal04 (McCormac et al., 2004). Marine ages were calibrated using Marine04 (Hughen et al., 2004) with relevant $\Delta \mathrm{R}$ correction (Ulm, 2002, 2006a; Ulm et al., 2009). Following calibration of the dataset, OxCal was used to sum the probabilities to produce time series graphs (Figures 2-3) and outputs for subsequent analysis.

Sum probability approaches and their interpretation have a number of limitations, which Smith et al. (2008) have discussed at length. Three further issues specific to this paper should be considered: (1) the lack of dating near the top of archaeological sequences, which are not routinely radiocarbon dated; (2) taphonomic bias in the archaeological records; and (3) the effect of radiocarbon plateaus.

Due to the frequent presence of European materials (indicating a date of $<200 \mathrm{ka}$ ) in the upper units of Australian archaeological sites, they are not routinely subject to radiometric analysis (e.g. Smith, 2006). For this reason, the dataset systematically lacks data in the last 200 years and changes in the sum probability during this period should be treated with caution.

Differential archaeological survivability and preservation may provide impact on changes in sum probability distributions, but it is considered unlikely that loss of archaeological data/sites would be consistent across the majority of latitudes and longitudes during this period. Other Australian studies suggest that the loss of archaeological data is generally localised (e.g. sea-level change submerging coastal sites, greater likelihood of sites being destroyed in storm and cyclone belts), rather than widespread (Bird, 1992; Hall, 1999). Taphonomic loss of sites, however, is a plausible explanation for the changes in numbers of archaeological sites within the last $5 \mathrm{ka} \mathrm{(Head,} \mathrm{1983;} \mathrm{Rowland,} \mathrm{1989;}$ Holdaway et al., 2008) and remains a limitation of the study. Based on taphonomic equations presented in Surovell et al. (2009), only $40 \%$ of archaeological sites may remain after $2 \mathrm{ka}$, and only $19 \%$ after $5 \mathrm{ka}$. It is further acknowledged that the greatest changes in the radiocarbon dataset are in areas where there is potential for significant flood erosion to occur, between AD 700-1000 and postAD 1500 (Bird, 1992). 

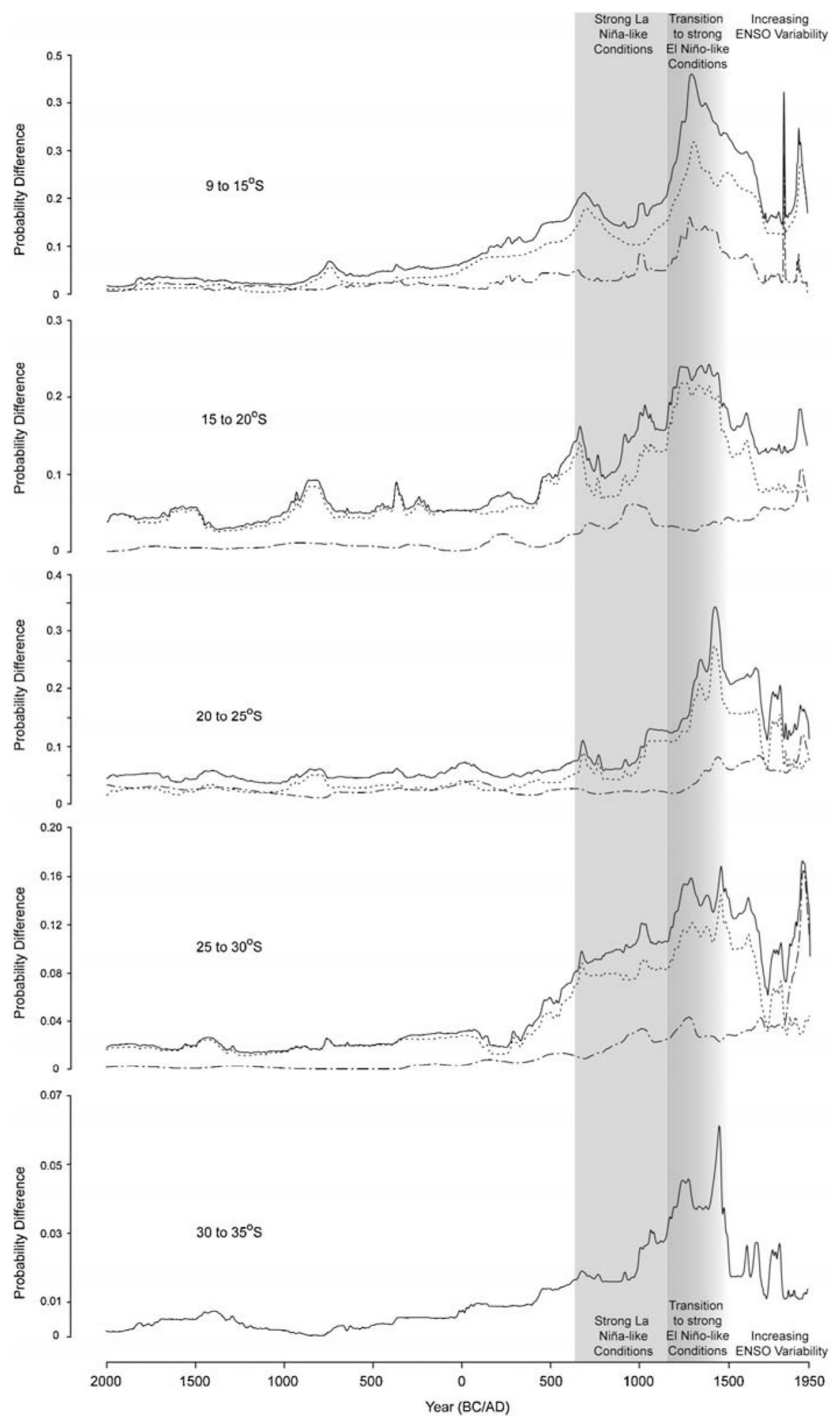

Figure 2. Sum probability distributions of 1275 radiocarbon dates (terrestrial, dashed line; marine, dot and dashed line; terrestrial and marine combined, solid line) from 608 archaeological sites across northern and central Australia, by latitudinal band. Note the lower latitudes did not retain any marine dates. 

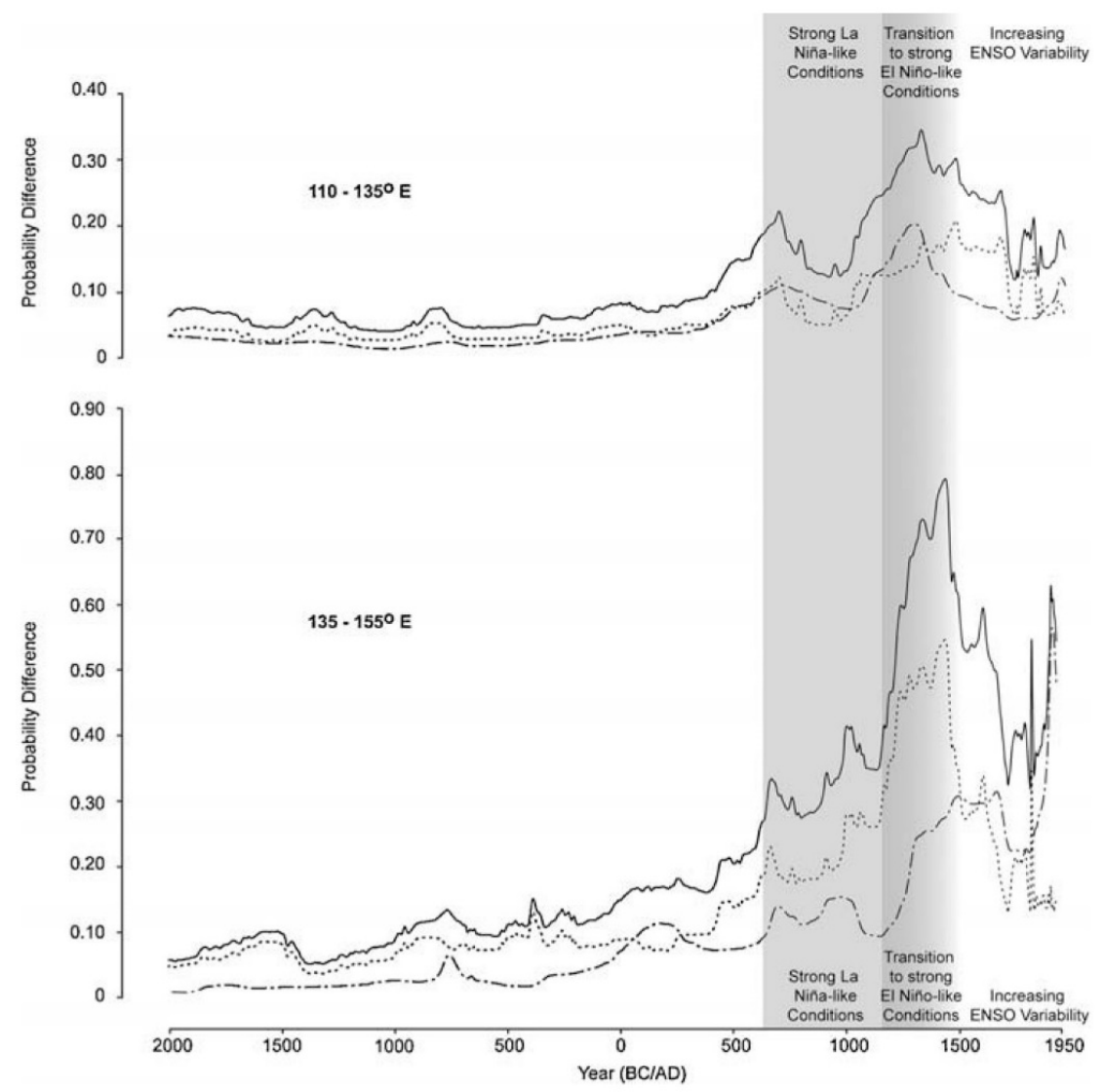

Figure 3. Sum probability distributions of 1275 radiocarbon dates divided between $110-135^{\circ} \mathrm{E}$ and $135-155^{\circ} \mathrm{E}$ dates (terrestrial, dashed line; marine, dot and dashed line; terrestrial and marine combined, solid line). 
A radiocarbon plateau centred on $\mathrm{AD} 1400$ may lead to clustered artificial peaks and troughs in this part of the sum probability curves (McCormac et al., 2004). Accordingly, we place most reliance on general trends in these datasets, rather than specific peaks/troughs. However, there are fewer than 100 dates within this part of the archaeological dataset (between 400 and 600 a BP) which we do not judge to have a significant effect on the robustness of the radiocarbon plots.

\section{Results}

Results show a general increase in the archaeological signature within all regions from ca. AD 450 and peaking between $\mathrm{AD} 1250$ and 1500, with two discrete declines between ca. AD 700 and 1000 and post-AD 1500:

(a) Latitudinal gradients demonstrate that the decline between AD 700 and 1000 is most marked in the lower latitudes $\left(9-20^{\circ} \mathrm{S}\right)$, encompassing the northern Australian coast, the Kimberley, Gulf of Carpentaria and Cape York Peninsula, but is not detectable in higher latitudes, including the Pilbara, Murchison, Great Sandy and Tanami Deserts, Flinders Ranges and Murray-Darling Basin. All latitudes experience a stepwise decline between AD 1500 and 1700 (Figure 2).

(b) The longitudinal data correlate well with the overall results (Fig. 3). When dividing the data between $110-135^{\circ} \mathrm{E}$ and $135-155^{\circ} \mathrm{E}$ (western and eastern Australia, respectively) there are clear differences in archaeological signature, most notably between AD 1000 and 1500, 110 $135^{\circ} \mathrm{E}$ - the western part of the continent - showing only a weak increase in archaeological signature when compared with the eastern half. In addition, data from $110-135^{\circ} \mathrm{E}$ show a sharp decline between AD 700 and 1000, but a weak response after AD 1400 AD. Conversely, the $135-155^{\circ} \mathrm{E}$ dataset reveals only a minor change between $\mathrm{AD} 700$ and 1000, but a significant decline after $\mathrm{AD} 1400$. Of further note are the two marine datasets, which show different responses to terrestrial data. Between 110 and $135^{\circ} \mathrm{E}$, the marine dataset shows a general absence of the initial decline but clear evidence of a decline after AD 1400, while $135-155^{\circ} \mathrm{E}$ appears to have a stepwise increase from AD 1000, reaching its highest levels only in recent years.

The most significant change in the sum probability distributions occurs in the terrestrial dataset between $15-25^{\circ} \mathrm{S}$ and $110-135^{\circ} \mathrm{E}$ in the northwestern sector of the continent.

\section{Discussion}

The climate of northern and central Australia is characterised by several drivers, notably the northern summer monsoons, cyclones and pseudo-monsoons in the Pilbara, and winter westerlies and frontal systems in the south (Sturman and Tapper, 1996; Donders et al., 2007). Changes in ENSO state play a significant role in the strength and location of these systems and thereby the amplitude, seasonality and variability of rainfall across large parts of Australia.

The history of ENSO activity in Australia has been extensively reviewed (e.g. Shulmeister, 1999; Gagan et al., 2004; Donders et al., 2007). Between ca. 3.7 and ca. 2 ka, ENSO intensified, causing significantly drier conditions and increased climatic variability, with subsequent amelioration from 2 $\mathrm{ka}$ to the present. However, more recent research indicates that the last 2 ka experienced significant 
changes in the tropical mode (ENSO) (Moy et al., 2002; Cobb et al., 2003; Rein et al., 2004) and the extratropical mode (Southern Annular Mode, SAM) (Goodwin et al., 2004; Goodwin and Mayewski, 2007).

Records from coral isotopes (Stott et al., 2004) and marine sediment cores (Rein et al., 2004) in the equatorial Pacific indicate an increase in zonal sea surface temperature gradients between AD 500 and 1000 , causing decreased frequency, variability and strength of the ENSO system, leading to drought conditions in South America, Central America (Rein et al., 2004) and California (Stine, 1994) and wetter conditions in Australia (Markgraf and Diaz, 2000; Goodwin and Mayewski, 2007; Mann et al., 2009). Evidence further suggests that this was one of the strongest La Niña-like and positive SAM periods since the mid Holocene and saw the intensification of monsoonal flow over the dry eastern interior and to the north and east, enhanced trade winds into Central Australia also dramatically increasing the availability of water and associated resources during this time (Bourke, 1998; Shulmeister, 1999; Rein et al., 2004; Donders et al., 2007; Williams et al., 2008a).

An intensification of El Niño-like and equator-ward negative SAM conditions occurred in the Australian region between AD 1300 and 1500 (Goodwin et al., 2004; Goodwin and Mayewski, 2007), which would have caused the movement of the Intertropical Convergence Zone (ITCZ) northwards, increased the anticyclonic conditions overlying the region, and thereby reduced the frequency of monsoon or rain-bearing low-pressure systems into the Australian interior (Suppiah, 1994; Sturman and Tapper, 1996; Kotwicki and Allan, 1998; Donders et al., 2007).

From about AD 1500 to the present increasing amplitude in the ENSO and Interdecadal Pacific Oscillation (IPO) states occurred and would have led to greater variability in the hydrological regime across Australia than earlier in the late Holocene (Markgraf and Diaz, 2000; Hendy et al., 2002; MacDonald and Case, 2005; Brockwell et al., 2009).

Our dataset shows a number of correlations between our understanding of the palaeoclimate and the archaeological records:

1. an Australia-wide increase in archaeological signatures coincident with the transition to La Niña-like conditions around AD 500-700;

2. a noticeable decline in archaeological signatures towards baseline levels, during the La Niñalike and positive SAM period between ca. AD 700 and 1000, evident in the lower latitudes (9$208 \mathrm{~S})$ and along the western and northwestern regions (110-1358 E), but not significant in eastern Australia;

3. a rapid increase in archaeological signatures, most marked between 135 and $1558 \mathrm{E}$, during the abrupt transition in ENSO state to persistent El Niño-like and negative SAM climate between AD 1150 and 1500;

4. a rapid decline towards baseline levels, and increasing fluctuation in archaeological signatures with the increase in ENSO and IPO variability from AD 1500 to the present.

While specific human responses to changing ENSO states cannot be derived using broad-scale sum probability distributions alone, other archaeological records allow some interpretation of these trends. 
Regional archaeological studies indicate that hunter-gatherer populations began to expand in many areas between 2.5 and $2 \mathrm{ka}$. Alternatively, some studies suggest this period saw a restructuring of land use with the greater use of more archaeological sites for shorter periods. Although the catalyst for these archaeological changes has yet to be determined, the initiation and changes in ENSO mean state are spatially and temporally correlated with the archaeological changes and causally linked through their impact on subsistence and settlement systems.

The reduction in archaeological signatures across the lower latitudes $\left(9-20^{\circ} \mathrm{S}\right)$ between $\mathrm{AD} 700$ and 1000 suggests that a disruption and/or reorganisation of hunter-gatherer settlement occurred in these regions. A decline in the archaeological record, generally indicative of population decline or abandonment, is hard to explain during a period of greater La Niña conditions (and thereby greater resource availability) when ethnographic accounts indicate that hunter-gatherers would have utilised a wider range of areas and resources, thereby increasing archaeological signatures. However, limited archaeological studies for these time periods do suggest hiatuses in hearth construction (Holdaway et al., 2002), shell mound building (Faulkner, 2008) and changing discard of artefactual material (McNiven, 1992; Ulm, 2006b), in inner New South Wales, western Arnhem Land and southeast Queensland, respectively, between ca. AD 800 and 1300. Given the intensity of La Niña-like conditions, increased flooding and storms are likely to have disrupted hunter-gatherer subsistence patterns in northern latitudes between AD 700 and 1000. In Arnhem Land, Meehan (1982) documented the destruction of several shell beds and the unavailability of freshwater after a period of intense La Niña-like conditions leading to shifts in settlement, and similar events may have occurred earlier in the Holocene. Increasing sedentism or a shift to logistical mobility strategies in these regions may also be a plausible explanation for a decline in archaeological records during periods of greater resource availability, but there is currently no ethnographic evidence for such a response.

In the higher latitudes $\left(20-35^{\circ} \mathrm{S}\right)$ there is no evidence of a decline in archaeological signature between AD 700 and 1000. This absence of a response suggests that if there was a hunter-gatherer response it was subdued in these regions and did not affect the archaeological signature across the landscape. The delayed hunter-gatherer response between 135 and $150^{\circ}$ E between AD 750-900 and AD 1215-1300 can be explained through change in hydrological regimes of the Diamantina Creek, Cooper Creek, Lake Eyre and Murray-Darling fluvial systems, and is consistent with an earlier abrupt change in climate state in the Indian Ocean sector than in the Pacific Ocean sector, as shown distinctively in East and West Antarctic ice cores (I. Goodwin, unpublished results).

The increasing archaeological signature between AD 1150 and 1500 - a period of transition to drying climate conditions - indicates an increase in hunter-gatherer mobility as a response to reduction in critical resources, including water, animal and plant foods in northern Australia. Changes in mobility are a first-order response by hunter-gatherers to changing environmental conditions and have often been cited in archaeological interpretations of resource stress in Australia (Hiscock and Veth, 1991; Hiscock, 1994; Black et al., 2008; Williams et al., 2008a). Archaeological studies identify a range of other hunter-gatherer responses to resource stress, including increasing use of marginal environments (e.g. use of offshore islands), increasing use of lower-ranked foods (e.g. acacia seeds and cycads) and the introduction of complex installations to improve productive yields (e.g. coastal and inland river fish traps) (Tonkinson, 1978; Smith, 1986; Haberle and David, 2004; Cosgrove et al., 2007; Brockwell et al., 2009), all of which would lead to an increase in the archaeological signatures evident in Figs 2 and 3 between AD 1150 and 1500. These responses are most evident along the east coast of Australia (135-1558 E; Fig. 3), which is unsurprising given the dominance of ENSO systems in these parts of Australia. 
We interpret the turbulent archaeological signatures after AD 1500 as hunter-gatherer responses to increasingly variable climatic conditions. This period saw marked climatic shifts that presumably led to rapidly changing resource landscapes. This would have required rapid adaptation and response by hunter-gatherers, which is reflected in the fluctuating sum probability distributions shown in Figures 2 and 3, and has also been documented by Black et al. (2008) in southeastern Australia.

\section{Conclusions}

Our results indicate that time series data and regional archaeological records correlate well with palaeoclimatic records for central and northern Australia over the last $2 \mathrm{ka}$. While uncertainties about hunter-gatherer responses remain, the correlation in timing between climatic change and radiometric determinations associated with human activities is unequivocal. Increasing archaeological signatures at AD 500-700 coincide with the onset of and transition to strong La Niña-like conditions across Australia. The highest archaeological signature values occur during the transition to El Niño-like climate, with increasing ENSO amplitude between AD 1150 and 1500. A lag in archaeological signature response between $110-135^{\circ} \mathrm{E}$ and $135-155^{\circ} \mathrm{E}$ is also considered to be related to an earlier transition from La Niña-like conditions to drier and more variable ENSO in the Indian Ocean sector than in the Pacific sector.

Of note in the archaeological records is the decline in signatures across the lower latitudes between AD 700 and 1000 and post-AD 1500. These periods broadly coincide with the Medieval Climatic Anomaly and Little Ice Age, which clearly register in palaeoclimatic records for the Pacific region (Allan, 1985; Mooney, 1997; Markgraf and Diaz, 2000; Hendy et al., 2002; Mooney and Maltby, 2006). Currently, the hunter-gatherer responses to these events cannot be adequately explained. However, it is evident that a disruption and/or reorganisation of resources did occur, most notably in the lower latitudes, at these times.

The results presented in this paper indicate that the changing state and amplitude of the ENSO circulation placed observable environmental stresses on prehistoric populations in Australia. We stress that further archaeological and palaeoclimatic data will be needed to characterise humanenvironment responses in detail.

\section{Acknowledgements}

A. W. was supported by the Fenner School of Environment and Society, the Australian National University and Archaeological and Heritage Management Solutions Pty Ltd. We thank L. Robin, P. Hiscock, P. Douglas, N. Williams, and C. S. M. Turney for suggestions and review. We thank the two unnamed reviewers for their advice and comment. We also thank Julie Leslie for her assistance with Figure 1. 


\section{References}

Allan RJ. 1985. The Australasian summer monsoon, teleconnections, and flooding in the Lake Eyre Basin. South Australian Geographical Papers 2. Royal Geographical Society of Australasia, SA Branch, Adelaide.

Attenbrow V. 2004. What's Changing: Population Size or Land-Use Patterns? The Archaeology of Upper Mangrove Creek, Sydney Basin (Terra Australis 21). Pandanus Books: Canberra.

Attenbrow V, Robertson G, Hiscock P. 2009. The changing abundance of backed artefacts in southeastern Australia: a response to Holocene climate change? Journal of Archaeological Science 36: $2765-2770$.

Barlow LK, Sadler JP, Ogilvie AEJ, Buckland PC, Amorosi T, Ingimundarson JH, Skidmore P, Dugmore AJ, McGovern TH. 1997. Interdisciplinary investigations of the end of the Norse Western Settlement in Greenland. The Holocene 7: 489-499.

Bird MK. 1992. The impact of tropical cyclones on the archaeological record: an Australian example. Archaeology in Oceania 27: 75-86.

Black MP, Mooney SD, Attenbrow V. 2008. Implications of a 14200 year contiguous fire record for understanding human-climate relationships at Goochs Swamp, New South Wales. The Holocene 18: $437-447$.

Bourke MCA. 1998. Fluvial geomorphology and paleofloods in arid Central Australia. PhD thesis, Australian National University, Canberra.

Brockwell S, Faulkner P, Bourke P, Clarke A, Crassweller C, Guse D, Meehan B, Sim R. 2009.

Radiocarbon dates from the Top End: a cultural chronology for the Northern Territory coastal plains. Australian Aboriginal Studies 1: 54-76.

Bronk Ramsey C. 2001. Development of the radiocarbon calibration program OxCal. Radiocarbon 43: 355-363.

Cobb KM, Charles CD, Cheng H, Edwards L. 2003. El Niño/Southern Oscillation and tropical Pacific climate during the last millennium. Nature 424: 271-276.

Cosgrove R, Field J, Ferrier A ${ }^{\circ}$. 2007. The archaeology of Australia's tropical rainforests.

Palaeogeography, Palaeoclimatology, Palaeoecology 251: 150-173.

Davidson I. 1990. Prehistoric Australian demography. In Hunter-Gatherer Demography: Past and Present, Meehan B, White N (eds). University of Sydney, Oceania Monograph 39: 41-58.

Diamond J. 2005. Collapse: How Societies Choose to Fail or Survive. Penguin: London.

Donders TH, Haberle SG, Hope G, Wagner F, Visscher H. 2007. Pollen evidence for the transition of the eastern Australian climate system from the post-glacial to the present-day ENSO mode. Quaternary Science Reviews 26: 1621-1637.

Edwards D, O’Connell JF. 1995. Broad spectrum diets in arid Australia. Antiquity 65: 769-783.

Faulkner P. 2008. Patterns of chronological variability in occupation on the coastal margin of Blue Mud Bay. Archaeology in Oceania 43: 81-88. 
Fiedel SJ, Kuzmin YV. 2007. Radiocarbon date frequency as an index of intensity of Palaeolithic occupation of Siberia: did humans react predictably to climate oscillations? Radiocarbon 49: 741-756.

Gagan MK, Hendy EJ, Haberle SG, Hantoro WS. 2004. Post-glacial evolution of the Indo-Pacific Warm Pool and El Niño-Southern Oscillation. Quaternary International 118-119: 127-143.

Gamble C, Davies W, Pettitt P, Hazelwood L, Richards M. 2005. Archaeological and genetic foundations of the European population during the Late Glacial: implications for 'agricultural thinking'. Cambridge Archaeological Journal 15: 193-223.

Goodwin I, Mayewski PA. 2007. Multi-decadal climate variability in the western Pacific and Antarctic regions during the past 1500 years. Quaternary International 167-168 (Suppl 1): 145.

Goodwin ID, van Ommen T, Curran M, Mayewski PA. 2004. Mid latitude climate variability in the south Indian and south-west Pacific regions since 1300 AD from the Law Dome ice core record. Climate Dynamics 22: 783-794.

Gould RA. 1969. Yiwara: Foragers of the Australian Desert. London: Collins.

Haberle S, David B. 2004. Climates of change: human dimensions of Holocene environmental change in low latitudes of the PEPII transect. Quaternary International 118-119: 127-143.

Hall J. 1999. The impact of sea level rise on the archaeological record of the Moreton region, southeast Queensland. In Australian Coastal Archaeology, Hall J, McNiven IJ (eds). Australian National University: Canberra; 169-184.

Head L. 1983. Environment as artefact: a geographic perspective on Holocene occupation of southwest Victoria. Archaeology in Oceania 18: 73-80.

Hendy EJ, Gagan MK, Alibert CA, McCulloch MT, Lough JM, Isdale PJ. 2002. Abrupt decrease in tropical Pacific sea surface salinity at end of Little Ice Age. Science 295: 1511-1514.

Hiscock P. 1994. Technological responses to risk in Holocene Australia. Journal of World Prehistory 8: $267-292$.

Hiscock P. 2008. Archaeology of Ancient Australia. Routledge: Abingdon, UK.

Hiscock P, Veth PM. 1991. Changes in the Australia desert culture: a reanalysis of tulas from Puntutjarpa rockshelter. World Archaeology 22: 332-345.

Holdaway SJ, Fanning PC, Jones M, Shiner J, Witter DC, Nicholls G. 2002. Variability in the chronology of late Holocene Aboriginal occupation on the arid margin of southeastern Australia. Journal of Archaeological Science 29: 351-363.

Holdaway SJ, Fanning P, Rhodes E. 2008. Challenging intensification: human-environment interactions in the Holocene geoarchaeological record from western New South Wales, Australia. The Holocene. 18: 403-412.

Hughen KA, Baillie MGL, Bard E, Beck JW, Bertrand CJH, Blackwell PG, Buck CE, Burr GS, Cutler KB, Damon PE, Edwards RL, Fairbanks RG, Friedrich M, Guilderson TP, Kromer B, McCormac G, Manning S, Bronk Ramsey C, Reimer PJ, Reimer RW, Remmele S, Southon JR, 
Stuiver M, Talamo S, Taylor FW, van der Plicht J, Weyhenmeyer CE. 2004. Marine04 marine radiocarbon age calibration, 0-26 cal kyr bp. Radiocarbon 46: 1059-1086.

Johnstone E, Macklin MG, Lewin J. 2006. The development and application of a database of radiocarbon-dated Holocene fluvial deposits in Great Britain. Catena 66: 14-23.

Kotwicki V, Allan R. 1998. La Niña de Australia: contemporary and palaeo-hydrology of Lake Eyre. Palaeogeography, Palaeoclimatology, Palaeoecology 144: 265-280.

Lourandos H, David B. 1998. Comparing long-term archaeological and environmental trends: north Queensland, arid and semiarid Australia. The Artefact 21: 105-114.

Lourandos H, Ross A. 1994. The great 'Intensification Debate': its history and place in Australian archaeology. Australian Archaeology 39: 54-63.

MacDonald GM, Case RA. 2005. Variations in the Pacific Decadal Oscillation over the past millennium. Geophysical Research Letters 32: LO8703.

Mann ME, Zhang Z, Rutherford S, Bradley RS, Hughes MK, Shindell D, Ammann C, Faluvegi G, Ni F. 2009. Global signatures and dynamical origins of the Little Ice Age and Medieval Climatic Anomaly. Science 326: 1256-1260.

Markgraf V, Diaz HF. 2000. The past ENSO record: a synthesis. In El Niño and the Southern Oscillation: Multiscale Variability and Global and Regional Impacts, Diaz HF, Markgraf V (eds). Cambridge University Press: Cambridge, UK; 465-488.

McCormac FG, Hogg AG, Blackwell PG, Buck CE, Higham TFG, Reimer PJ. 2004. SHCal04 Southern Hemisphere calibration, 0-11.0 cal kyr bp. Radiocarbon 46: 1087-1092.

McNiven I. 1992. Sandblow sites in the Great Sandy region, coastal southeast Queensland: implications for models of late Holocene rainforest exploitation and settlement restructuring. Queensland Archaeological Research 9: 1-16.

Meehan B. 1982. Shellbed to Shell Midden. Australian Institute of Aboriginal Studies: Canberra. Meggitt MJ. 1962. Desert People: A study of Walbiri Aborigines of Central Australia. Angus \& Robertson: Sydney.

Mooney SD. 1997. A fine resolution palaeoclimatic reconstruction of the last 2000 years, from Lake Keilambete, southeastern Australia. The Holocene, 7: 139-149.

Mooney SD, Maltby EL. 2006. Two proxy records revealing the late Holocene fire history at a site on the central coast of New South Wales, Australia. Austral Ecology 31: 682-695.

Moy CM, Seltzer GO, Rodbell DT, Anderson DM, 2002. Variability of El Niño/Southern Oscillation activity at millennial timescales during the Holocene epoch. Nature 420: 162-165.

Myers FR. 1991. Pintupi Country, Pintupi Self. University of California Press: Berkeley, CA.

Nunn P. 2003. Nature-society interactions in the Pacific Islands. Geografiska Annaler: Series B 85: 219-229. 
Pennington R. 2001. Hunter-gatherer demography, In Hunter-Gatherers: An Interdisciplinary Perspective. Panter-Brick C, Layton RH, Rowley-Conwy P (eds). Cambridge University Press: Cambridge, UK; 170-204.

Rein B, Lückge A, Sirocko F. 2004. A major Holocene ENSO anomaly during the Medieval period. Geophysical Research Letters31:L17211.

Rick JW. 1987. Dates as data: an examination of the Peruvian preceramic radiocarbon record. American Antiquity 52: 55-73.

Ross A. 1986. Archaeological evidence for population change in the middle to late Holocene in southeastern Australia. Archaeology in Oceania 20: 81-89.

Rowland M. 1989. Population increase, intensification or a result of preservation? Explaining site distribution patterns on the coast of Queensland. Australian Aboriginal Studies 1989: 32-42.

Shulmeister J. 1999. Australasian evidence for mid-Holocene climate change implies precessional control of Walker Circulation in the Pacific. Quaternary International 57/58: 81-91.

Smith MA. 1986. The antiquity of seed grinding in arid Australia. Archaeology in Oceania 21: 29-39.

Smith MA. 2006. Characterizing late Pleistocene and Holocene stone artefact assemblages from Puritjarra rock shelter: a long sequence from the Australian desert. Records of the Australian Museum 58: $371-410$.

Smith MA, Ross J. 2008. What happened at 1500-1000 BP in central Australia? Timing, impact and archaeological signatures. The Holocene 18: 387-396.

Smith MA, Williams AN, Turney CSM, Cupper M. 2008. Human environment interactions in Australian drylands: exploratory timeseries analysis of archaeological records. The Holocene 18: 389-401.

Stine S. 1994. Extreme and persistent drought in California and Patahonia during Mediaeval time. Nature 369: 546-549.

Stott L, Cannariato K, Thunell R, Haug GH, Koutavas A, Lund S. 2004. Decline of surface temperature an salinity in the western tropical Pacific ocean in the Holocene epoch. Nature 431: 5659.

Sturman A, Tapper N. 1996. The Weather and Climate of Australia and New Zealand. Oxford University Press: Oxford.

Suppiah R. 1994. Synoptic aspects of wet and dry conditions in central Australia: observations and GCM simulations for 1TCO2 and 2TCO2 conditions. Climate Dynamics 10: 395-405.

Surovell TA, Brantingham PJ. 2007. A note on the use of temporal frequency distributions in studies of prehistoric demography. Journal of Archaeological Science 34: 1868-1877.

Surovell TA, Byrd Finley J, Smith GM, Brantingham PJ, Kelly R. 2009. Correcting temporal frequency distributions for taphonomic bias. Journal of Archaeological Science 36: 1715-1724. 
Tainter JA, Crumley CL. 2007. Climate, complexity, and problem solving in the Roman Empire. In Sustainability of Collapse? An Integrated and Future of People on Earth, Costanza R, Graumlich LJ, Steffen W (eds). MIT Press: Cambridge, MA; 61-76.

Thorley P. 1998. Pleistocene settlement in the Australian arid zone: occupation of an inland riverine landscape in the central Australian ranges. Antiquity 72: 34-45.

Tonkinson R. 1978. The Mardudjara Aborigines: Living the Dream in Australia's Desert. Holt, Rinehart \& Winston: New York.

Turney CSM, Hobbs D. 2006. ENSO influence on Holocene Aboriginal populations in Queensland, Australia. Journal of Archaeological Science 33: 1744-1748.

Turney CSM, Baillie M, Palmer J, Brown D. 2006. Holocene climatic change and past Irish societal response. Journal of Archaeological Science 33: 34-38.

Ulm S. 2002.Marine and estuarine reservoir effects in central Queensland, Australia: determination of $\Delta \mathrm{R}$ values. Geoarchaeology 17: 319-348.

Ulm S. 2006a. Australian marine reservoir effects: a guide to $\Delta \mathrm{R}$ values. Australian Archaeology 63: $57-60$.

Ulm S. 2006b. Coastal Themes: An Archaeology of the Southern Curtis Coast, Queensland. ANU E Press: Canberra.

Ulm S. 2010. Costal foragers on southern shores: marine resource use in northeast Australia since the late Pleistocene. In Trekking the Shore: Changing Coastlines and the Antiquity of Coastal Settlement, Bicho N, Haws J, Davis L (eds). Springer: New York; (in press).

Ulm S, Reid J. 2000. Index of dates from archaeological sites in Queensland. Queensland Archaeological Research 12: 1-129.

Ulm S, Petchey F, Ross A. 2009. Marine reservoir corrections for Moreton Bay. Archaeology in Oceania 43: 160-168.

Veth PM. 1993. Islands in the Interior: The Dynamics of Prehistoric Adaptations within the Arid Zone of Australia, Archaeology Series 3 International Monographs in Prehistory: Ann Arbor, MI.

Veth PM. 2005. Cycles of aridity and human mobility: risk minimisation among Late Pleistocene foragers of the Western Desert, Australia. In Desert Peoples: Archaeological Perspectives, Veth PM, Smith MA, Hiscock P (eds). Blackwell: Melbourne; 100-115.

Williams AN, Santoro CM, Smith MA, Latorre C. 2008a. The impact of ENSO in the Atacama desert and Australian arid zone: exploratory time-series analysis of archaeological records. Chungara, Revista de Antropologi'a Chilena 40: 245-259.

Williams AN, Smith MA, Turney CSM, Cupper M. 2008b. Austarch1: a database of 14C and luminescence ages from archaeological sites in the Australian arid zone. Australian Archaeology 66: 99.

Williams E. 1988. The archaeology of lake systems in the middle Cooper Basin, northeastern Australia. Records of the South Australian Museum 22: 53-62. 